\title{
Autologous-Cell Melanoma Vaccine
}

National Cancer Institute

\section{Source}

National Cancer Institute. Autologous-Cell Melanoma Vaccine. NCI Thesaurus. Code C1981.

An autologous-cell vaccine for melanoma. 